\title{
ONLINE TEACHING IN LOCKDOWN: ANALYSIS OF THE USAGE BEHAVIOUR OF COLLABORATIVE TOOLS BY STUDENTS AND TEACHERS IN THE CONTEXT OF HIGHER EDUCATION AND VOCATIONAL EDUCATION
}

\author{
Görl-Rottstädt $\mathrm{D}^{1^{*}}$, Heinrich-Zehm $\mathrm{M}^{1}$, Arnold $\mathrm{M}^{1}$, Köhler $\mathrm{M}^{1}$ and \\ Hähnlein $\mathrm{V}^{2}$ \\ ${ }^{1}$ University of Applied Sciences Dresden (FHD), Germany \\ ${ }^{2}$ Catholic University of Applied Sciences Berlin (KHSB), Germany
}

\begin{abstract}
Due to the SARS-CoV-2 pandemic, many changes can be observed in almost all life situations, perhaps most notably, in the educational sector. In this context, concepts of learning counselling must be given more attention. This research contribution examines the question of how collaborative online tools to support the teaching-learning processes in higher education and vocational schools can be utilized. The aim is to improve the existing learning environment. For this purpose, the frequency of the usage of tools such as tests and forums on an open-source online learning platform ILIAS ${ }^{\mathrm{TM}}$ was analysed and discussed. In addition, the Adobe Connect ${ }^{\mathrm{TM}}$ web meeting software to be used in online teaching scenarios was also included in our investigation to explore the exchange of participants via discussion forums or virtual classrooms. The research team carried out an online sampling survey of ILIAS ${ }^{\mathrm{TM}}$ users at one university and five vocational schools in Germany in June 2020. The survey included these measures: Single answers, multiple answers, questions of scale, and free text questions. The response rate at the university was $25.10 \%$ and at the vocational schools $17.2 \%$. The data were evaluated with the help of descriptive statistics to determine frequency distributions and mean value calculations. This contribution will lead to a discussion regarding the continued disclosure of the learning potentials about a useful combination of both tools ILIAS ${ }^{\mathrm{TM}}$ and Adobe Connect ${ }^{\mathrm{TM}}$. The results shown suggest that the development towards virtual teaching scenarios, which has become a necessity under the forced conditions of the lockdowns, has a tremendous effect on teaching and learning processes in terms of didactics tailored to different target groups and needs in and outside the classroom.
\end{abstract}

Keywords: Learning Consulting, Collaborative Learning, ILIAS ${ }^{\mathrm{TM}}$, Adobe Connect ${ }^{\mathrm{TM}}$

\section{Introduction}

Due to internal and external events, such as the COVID 19 pandemic, there are manifold changes observable in most life situations, thus also in pedagogical contexts of the educational sector. In this context, educational concepts, especially the resulting challenges for learning guidance and counselling, must be considered critically.

This paper, therefore, explores the question of how the use of online-based collaborative tools - the online learning platform ILIAS ${ }^{\mathrm{TM}}$ and the video conferencing software Adobe Connect ${ }^{\mathrm{TM}}-$ can 
support teaching-learning processes in higher and vocational education contexts. The survey aims to examine the media competence of the actors in using the tools to conclude the extent to which the tasks of learning guidance and learning support have been implemented or where barriers do exist.

For this purpose, the contribution first introduces the concepts of learning guidance and learning support. Based on this, the tasks for learning counsellors and learning guides are presented and aligned to the necessity in high school apprenticeships and vocational schools. Afterwards, the paper will present findings from the analysis of digital tools in teaching-learning processes concerning lecturers, students, and pupils at a university of applied sciences and at five vocational schools in Germany between 5 June and 12 June 2020. Finally, approaches to digital learning guidance and learning support will be derived from the results shown.

\section{Theoretical foundations}

In the following section, the theoretical foundations of pedagogical concepts, online-based learning platforms, and web conferencing tools will be presented.

\section{Basically concepts: learning counselling and learning support}

In this context, concepts of learning guidance and learning support must be increasingly focused on. These concepts focus on self-organized learning (cf. Promotionskolleg Lebenslanges Lernen, 2003:15; Siebert, 2011:19; Kubrická:2020; Gössling/Daniel: 2018), whereby the intention lies on developing new learning cultures, which is discussed in versatile enabling didactics (cf. Wiesner et al., 2002a:12; Nolda, 2012:38 ff.) and emphasized in the practical implementation of actiontheoretical concepts (cf. Heyse/Erpenbeck, 1997). Following Pätzold, learning guidance and learning counselling are understood as activities "to help learners determine their learning needs, derive learning goals, identify learning resources, develop a strategy, implement it, and evaluate their own learning success." (Pätzold, 2004:7; transl. by authors). "Learning guidance" must be considered in both the tasks of the lecturers as learning advisors or learning guides (Wiesner et al., 2002a, 2002b; transl. by authors) and the recording of adult pedagogical competences in the work situation (cf. Böhm et al., 2009:1-14; Wiesner et al., 2009a:6, 2009b:5 ff., 2009c:5 ff.). Based on the discussions on self-directed learning in the 1970s (cf. e.g., Kruse/Wiesner, 2002:159-175; Wiesner et al., 2002a, 2002b), it seems worthwhile to further develop the ideas formulated in the sense of a digitalized method suitcase (cf. Dyrna et al., 2018:155-166'1).

Previous research (Wiesner et al., 2002b) has shown that teachers in this context can be understood as learning advisors, learning designers, learning facilitators, moderators, or coaches and should be able to perform the activities:

- Providing adequate learning arrangements.

- Analysis of existing learning strategies and support for changing them, if necessary.

- Providing learners' orientation.

- Supporting learners in monitoring the learning outcomes.

\footnotetext{
${ }^{1}$ A collection of methods and tools to support the professional development of teachers can also be found at https://methodenkoffer-sgl.de, in addition to the publication mentioned above.
} 
- Support to uncover barriers to learning.

- Encourage learners' engagement with learning offers.

- Support to discover learning needs.

- Advising learners in making decisions about learning paths.

- Advising learners in making decisions about learning content.

The immediate challenge is to transfer the tasks of learning guidance and learning support to virtual teaching and learning spaces. When dealing with digital tools, there need to be considered advantages and disadvantages of the digitisation process from a didactic viewpoint. The obvious advantages are the development of media competence and flexibility in terms of location and time and automation approaches. However, the activation of participants before, during, and after using digitalised tasks still requires a high level of attention that should not be underestimated (Görl-Rottstädt et al., 2020; Görl-Rottstädt et al., in press). For the technical implementation, there are numerous forms of offerings available within or outside of known learning platforms. In addition to the more traditional and familiar approaches of e-mail, phone, and personal counselling (Görl-Rottstädt et al., in press), lecturers had to explore in more depth the learning management system (LMS) ILIAS ${ }^{\text {TM }}$ used at the university and vocational school. Here, among other things, the lecturers primarily pursue a lowthreshold approach to digital support. Simple functions such as upload, test, forum, or exercise are integrated to accompany the development stages in the processing of the assignment. Particularly against the background of the pandemic-related restrictions during the study phase, the use of the learning platform ILIAS ${ }^{\mathrm{TM}}$ with the web conferencing software Adobe Connect ${ }^{\mathrm{TM}}$ and its specific elements for synchronous collaboration was intensified. With the presented approach of digitally supported learning guidance and counselling, the concern of media competence enhancement can be systematically supported (Görl-Rottstädt/Pittius, 2018; Görl-Rottstädt et al., 2020; Görl-Rottstädt et al., in press).

\section{Online-supported learning platform ILIAS}

Online learning platforms offer the opportunity of providing online tutorials, audio visually prepared case studies, electronic books, information databases, journals, or e-learning programs. Learning platforms have advanced features, such as forums, chat rooms, or newsgroups, besides the prepared learning content. The online-supported learning platforms can be used in a relatively straightforward way in everyday teaching. An interactive exchange among each other is possible (cf. Moriz, 2008:20). In this context, ILIAS ${ }^{\text {TM }}$ is one of the numerous online learning platforms whose name is derived from the acronym for "Integrated Learning, Information and Work Coordination System" (ILIAS open-source e-Learning e.V., 2020). ILIAS ${ }^{\mathrm{TM}}$ is based on the user design of a library. All users have their own "personal desk" which intuitively works like a digital workstation. All relevant functions of ILIAS $^{\text {TM }}$ can be accessed from the personal desk. In ILIAS ${ }^{\text {TM }}$, there are various learning tools that teachers can use to structure the respective learning environment (cf. ibid.). These include above all the following time- and access-controlled elements: 
Table 1. Tools in ILIAS ${ }^{\mathrm{TM}}$ (cf. ILIAS ${ }^{\mathrm{TM}}$ open-source e-Learning e.V., 2020).

\begin{tabular}{|c|c|}
\hline Functionality & Description \\
\hline Folders and files & $\begin{array}{l}\text { Folders and files allow the upload of digital learning materials of all kinds: } \\
\text { e.g. texts, audio/video files, HTML. }\end{array}$ \\
\hline Sessions & Sessions are used to plan and structure courses. \\
\hline Exercises, tests, and surveys & $\begin{array}{l}\text { Exercises, tests, and surveys are suitable for the creation of (self-) learning } \\
\text { tests and exams for both self and external assessment. They offer different } \\
\text { question types (e.g. single/multiple choice, cloze, assignment and } \\
\text { arrangement tasks, imagemaps, free texts, etc.) and can be programmed } \\
\text { based on various parameters (access to question pools, order, completion } \\
\text { time, assessment, differentiated presentation of results). Sessions can plan } \\
\text { and structure courses. }\end{array}$ \\
\hline Wikis, forums & $\begin{array}{l}\text { Collaborative tools for synchronous and asynchronous collaboration and } \\
\text { communication: e.g. wikis, forums (with moderation/evaluation and } \\
\text { notification functions), and chat (with chat rooms for courses and groups and } \\
\text { public rooms). }\end{array}$ \\
\hline Learning portfolios & $\begin{array}{l}\text { Learning portfolios can be used for different didactic purposes, application } \\
\text { examples, and target groups and serve the structured presentation of } \\
\text { individual competence profiles and general learning achievements (incl. } \\
\text { release and commenting options). }\end{array}$ \\
\hline Working groups & $\begin{array}{l}\text { Workgroups provide opportunities for several course members to } \\
\text { collaborate, each creating and sharing their learning materials. }\end{array}$ \\
\hline Authoring tool & $\begin{array}{l}\text { Learning modules have an integrated authoring tool that can create web- } \\
\text { based training (e.g. HTML, SCROM). In principle, learners can be provided } \\
\text { with the aforementioned learning tools and Internet-compatible content in a } \\
\text { self-contained learning unit. }\end{array}$ \\
\hline
\end{tabular}

ILIAS $^{\mathrm{TM}}$ offers the possibility to extend created courses, folders, etc. with additional personalized information using the "Edit page" function. Likewise, all elements created in ILIASTM can be exported and re-imported elsewhere, such as in the Adobe Connect web conferencing software.

\section{Adobe Connect ${ }^{\mathrm{TM}}$ web conferencing software}

With telecommunications networks, e-communication is possible, meaning an exchange of participants with spatial distance in teaching and learning processes via discussion forums or so-called virtual classrooms (cf. Euler \& Seufert, 2005, I: 5), helped by which virtual presentations, lectures, training, or video conferences are possible. A web conference is a one-to-many communication, where lecturers sit in front of a screen and make it accessible to their audience via desktop sharing. The voice of the lecturer is transmitted by telephony or VoIP (Internet telephony) (cf. Hermann-Ruess \& Ott, 2014: 2-7).

The Adobe Connect ${ }^{\mathrm{TM}}$ software is a widely used web conferencing software that enables online meetings and virtual classrooms. In addition to audio communication, through a microphone video communication via web camera is also possible. The learning environment consists of a virtual meeting room, which is "set up" with so-called pods (=windows). Using a pod menu, the moderator/organizer can design the meeting room themselves as follows, see Table 2 below (cf. Adobe Systems Software Ireland Limited, 2020). 
Table 2. Tools in Adobe Connect ${ }^{\mathrm{TM}}$ (cf. Adobe Systems Software Ireland Limited, 2020).

\begin{tabular}{|c|c|}
\hline Functionality & Description \\
\hline Chat pod & $\begin{array}{l}\text { The Chat-Pod enables in-meeting communication without interrupting the } \\
\text { ongoing dialog. You can chat with the entire group or privately with } \\
\text { individual participants. The chat content can be saved via email for later use. }\end{array}$ \\
\hline Share pod & $\begin{array}{l}\text { The Share pod summarizes three sub-functions: 1.) Uploading files } \\
\text { (including image files, flash files), PowerPoint, MP3, MP4, and ZIP files. } \\
\text { Presentations are also available. 2.) Sharing a whiteboard. Text and drawing } \\
\text { tools can create whiteboard images. 3.) Sharing the screen or parts of the } \\
\text { screen. This can be used for desktop sharing as an alternative to document } \\
\text { sharing, but also web pages, etc. }\end{array}$ \\
\hline Voting pod & $\begin{array}{l}\text { The Voting pods allow participants to vote using multiple-choice, multi- } \\
\text { answer, or free text questions. The result can be provided to the group of } \\
\text { participants. }\end{array}$ \\
\hline Notice pod & The Note pod can be used for creating shortlists, notes, tasks, etc. \\
\hline Download pod & $\begin{array}{l}\text { Meetings in Adobe Connect } \\
\text { cannot be present can participate in a time-delayed manner. All this must be } \\
\text { done only in compliance with privacy and copyright laws. When } \\
\text { downloading, the content of the individual pods can be specifically } \\
\text { deactivated. }\end{array}$ \\
\hline Status function & $\begin{array}{l}\text { The status function provides information about the individual participants, } \\
\text { partly in the form of symbols. Besides the reporting function, there is also } \\
\text { "agree/disagree", "speak louder/quieter", "faster/slower", "laugh", } \\
\text { "applause", etc.). }\end{array}$ \\
\hline Workgroup pod & $\begin{array}{l}\text { Workgroup pod: The main room can be divided into smaller virtual sub- } \\
\text { rooms (e.g. for group work). The organizers can also "enter" these rooms } \\
\text { individually to provide support or answer questions. Chat pod, whiteboard, } \\
\text { and screen sharing are also available. }\end{array}$ \\
\hline
\end{tabular}

\section{Methodology}

The survey of the selected university of applied sciences and vocational schools has shown itself to be a great speciality and an opportunity due to the current experiences with the special challenges of the COVID pandemic. The research team itself is affected by the situation and has recognized it as a necessity to map a snapshot of implementing digital teaching with this survey, to derive valuable indications for further didactic developments and improvements from the results.

Since the educational institution of the university of applied sciences is also responsible for five vocational schools at different locations in Germany, it was possible to extend the survey also to the vocational school sector during the development of the research design.

Both universities of applied sciences and vocational schools face the same challenges. The possibility of now carrying out a comparative analysis to gain similarities and differences in dealing with the current teaching-learning situation is an immense opportunity that could be used. Especially here the cross-institutional cooperation in the research process promises the creation of important impulses for further cooperation and exchange of experiences among the teachers.

Considering the quantitative methodological approach to data collection in constructing an online questionnaire (Bortz and Döring, 2006:253) the surveys were developed to obtain information on these aspects: 
- The previous experiences and usage possibilities of virtual offerings,

- The use of digital end devices for the virtual teaching-learning process,

- The use of digital tools from ILIAS ${ }^{\mathrm{TM}}$ and Adobe Connect ${ }^{\mathrm{TM}}$,

- Future relationship between online and face-to-face teaching and

- Future use of digital tools after the pandemic.

For the research project, an online survey was conducted by the research team in the period from Jun $5^{\text {th }}$ to June $12^{\text {th }}, 2020$, at a university of applied sciences and five vocational schools in three German (major) cities. The survey used single-response, multiple-response, scale questions, and free-text questions. The basic population on the cut-off date of June $5^{\text {th }}$, 2020, consists of employed teachers, honorary lecturers, students, and pupils. 135 people participated in the survey of the University of Applied Sciences, which corresponds to a response rate of $25.10 \%$ out of 526 people contacted by email. In the survey of the vocational schools, 418 persons of 2,430 people contacted participated, with a response rate of $17.2 \%$. The data were analysed using descriptive statistics to determine frequency distributions and mean value calculations with the statistical software SPSS (Brosius, 2017)

This paper investigates the use of online collaborative tools to support teaching-learning processes in higher education and vocational training contexts. For this purpose, we investigate the frequency of tools (e.g., tests, forums, chat rooms or wikis, etc.) of the online learning platform ILIAS ${ }^{\mathrm{TM}}$. In addition, the tools used for online teaching in the Adobe Connect ${ }^{\mathrm{TM}}$ software are included in the study.

The following chapter will present the results of the survey on using the two mentioned tools.

\section{Results}

\section{Socio-demographic analysis}

The overall response of the respective samples shows - as usual in surveys in educational institutions - high participation of students and pupils. The percentage distribution of students and pupils was over $80 \%$ for both the university and the schools. The distribution of honorary lecturers and full-time teachers between the comparison groups is interesting too. At the university, $12.7 \%$ of all responses were provided by honorary lecturers compared to only $0.73 \%$ at the schools. In the case of full-time lecturers, $3.17 \%$ of the questionnaires were received from the university compared to $13.17 \%$ in the schools. The gender characteristics were distributed as follows: At the university, $75.19 \%$ indicated that they were of female gender (male: $24.03 \%$, diverse: $0.78 \%$ ). At the vocational schools, the distribution is similarly distributed: females $(72.47 \%)$, males $(26.32 \%)$, and diverse with $1.21 \%$. Student's birth years vary from the 1980 s to the 2000 s. Part-time students' or learners', but especially apprentices', the age range varies from the 1940s to the 1970s.

\section{Digitization of teaching-learning processes}

For participation in virtual courses, the question arises as to the use of technical devices. 
The respondents were allowed to specify their technological access with multiple responses, resulting in these findings, see figures 1 and 2. Above all, access to virtual learning environments takes place with laptops and PCs (cumulatively at approx. 63\% at the university and 60\% at the school). The increased use of smartphones in schools appears to be interesting. In this educational context, laptops, PC and smartphones cover approx. 90\% of the usage behaviour of technical end devices. At the University of Applied Sciences, this is still distributed more between smartphones and tablets.

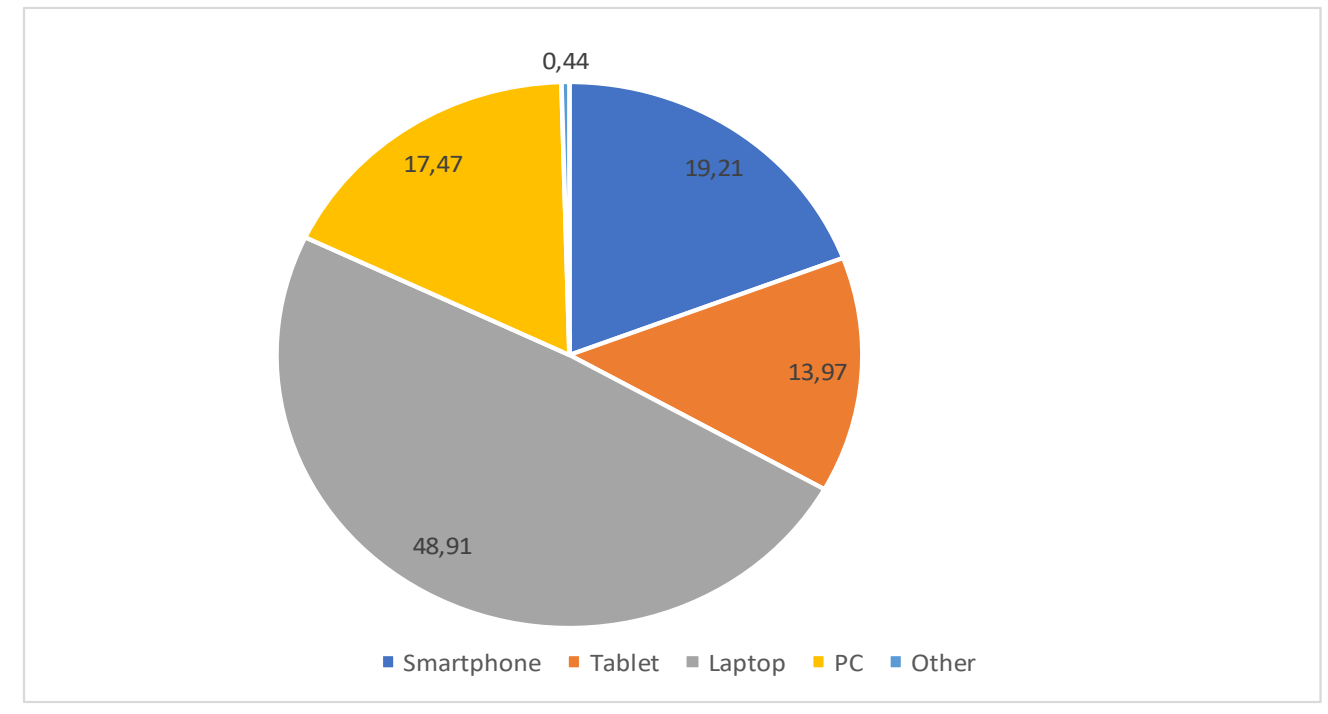

Figure 1. Use of technical devices (university of applied sciences)

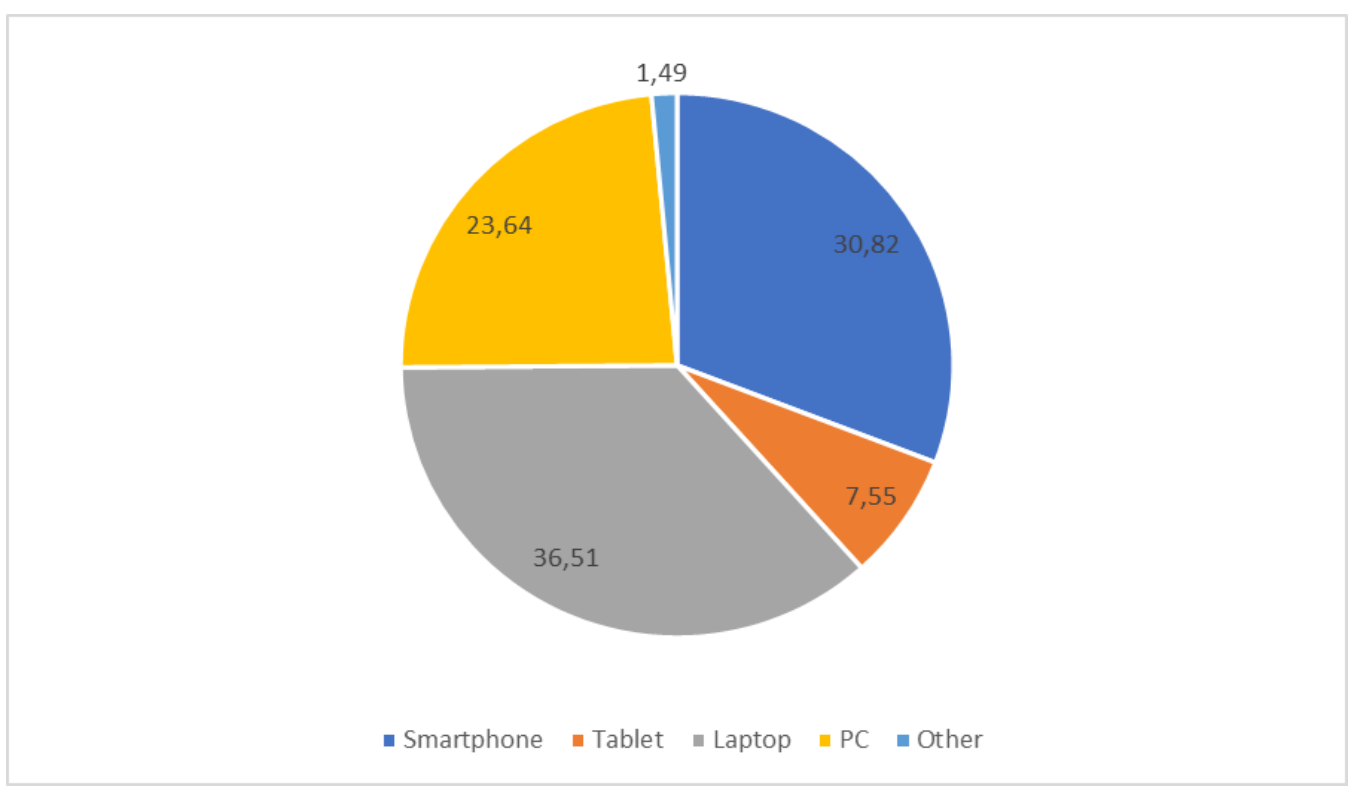

Figure 2. Use of technical end devices (vocational schools)

A comparison of the mean values shows that most of the topics covered in the courses or lessons are obtained by using information from the internet. This also includes a very intensive exchange in virtual group contexts. YouTube ${ }^{\mathrm{TM}}$ offerings have also become increasingly important as a source of information. Furthermore, the survey asked about experiences with virtual learning environments before the COVID 19 pandemic. Here respondents for the different institutions had only limited 
experience with virtual learning environments in the run-up to the lockdown. For all variables, the median is like the mean and the $\chi^{2}$ significance is $\mathrm{p}=0.000$.

\section{Using ILIAS ${ }^{\mathrm{TM}}$ and Adobe Connect ${ }^{\mathrm{TM}}$ tools}

As already described in the previous sections, the ILIAS ${ }^{\mathrm{TM}}$ learning platform provides various tools to generate interactivity in the learning groups and between teachers and learners. The corresponding usage activity is shown in the mean value comparison of the two samples in figure 3. All tools of ILIAS $^{\text {TM }}$ are used by the respondents, although the intensity within and between the educational institutions is very different. The tools "Forum" and "Exercise" have similar importance in the application, whereas the tools "Test" and "Wiki" are used more in the school context. The learning module was a particular focus of the work at both institutions.

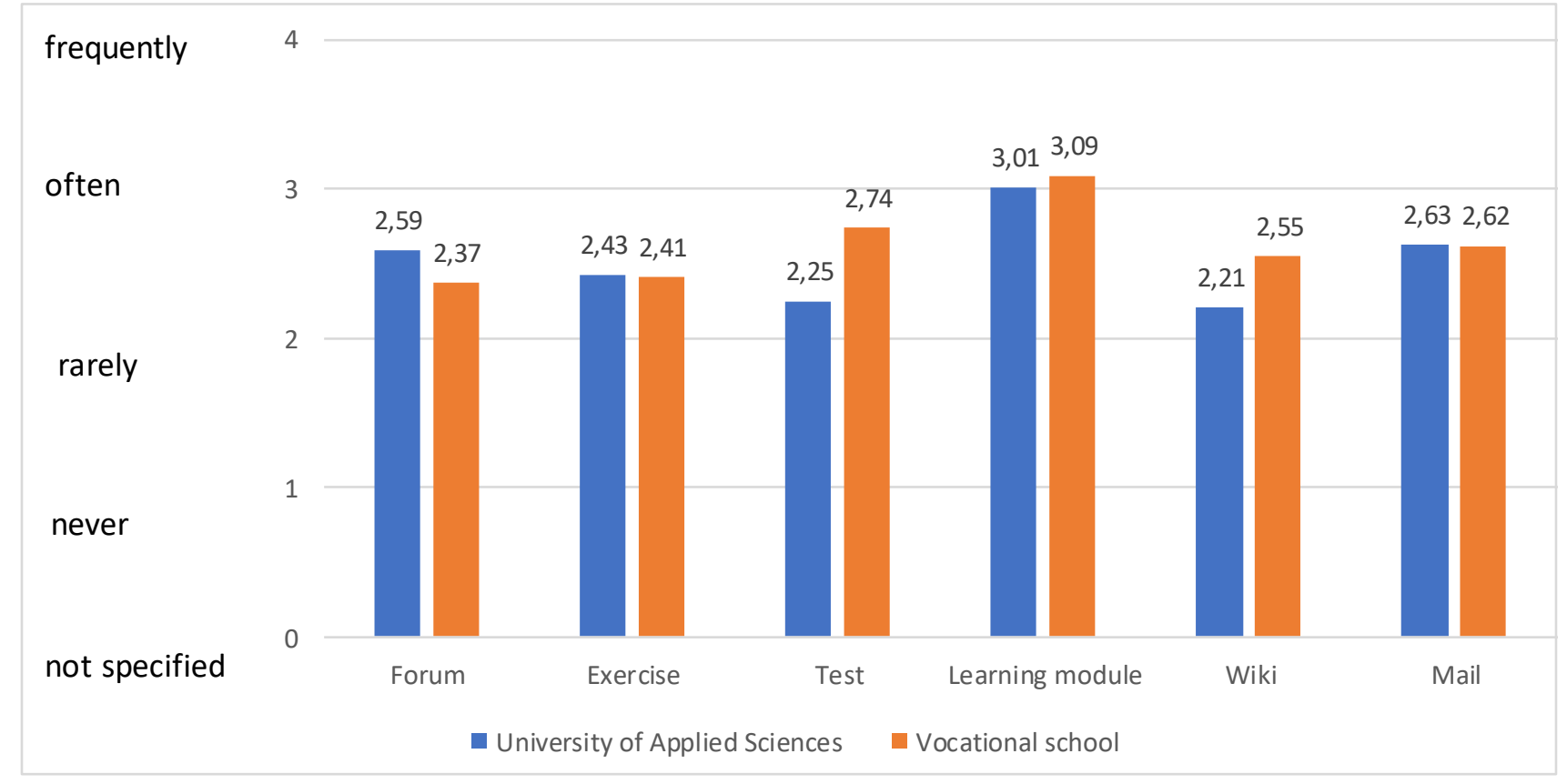

Figure 3. Use of the ILIAS ${ }^{\mathrm{TM}}$ tools (Mean comparison)

In principle, the median and mean values of all cohorts are relatively similar. Only with the vocational schools surveyed, the median deviates from the "Wiki" tool and lies at the value "never". It should be emphasized that with exception of the "learning modules", the significance checks according to $\chi^{2}$ show a high probability of $\mathrm{p}=0.000$.

The Adobe Connect ${ }^{\mathrm{TM}}$ virtual learning environment also provides tools for increasing user activity and stimulating group activity. For example, in the higher education context, the preference seems for chat and microphone, followed by a presentation, status, and participation in virtual workgroups. In the school context, file storage, presentation, screen sharing, the whiteboard, and status and hint functions are increasingly integrated into the teaching-learning process. Given the sample size, it can be assumed that target group-oriented preferences are reflected here (figure 4). 


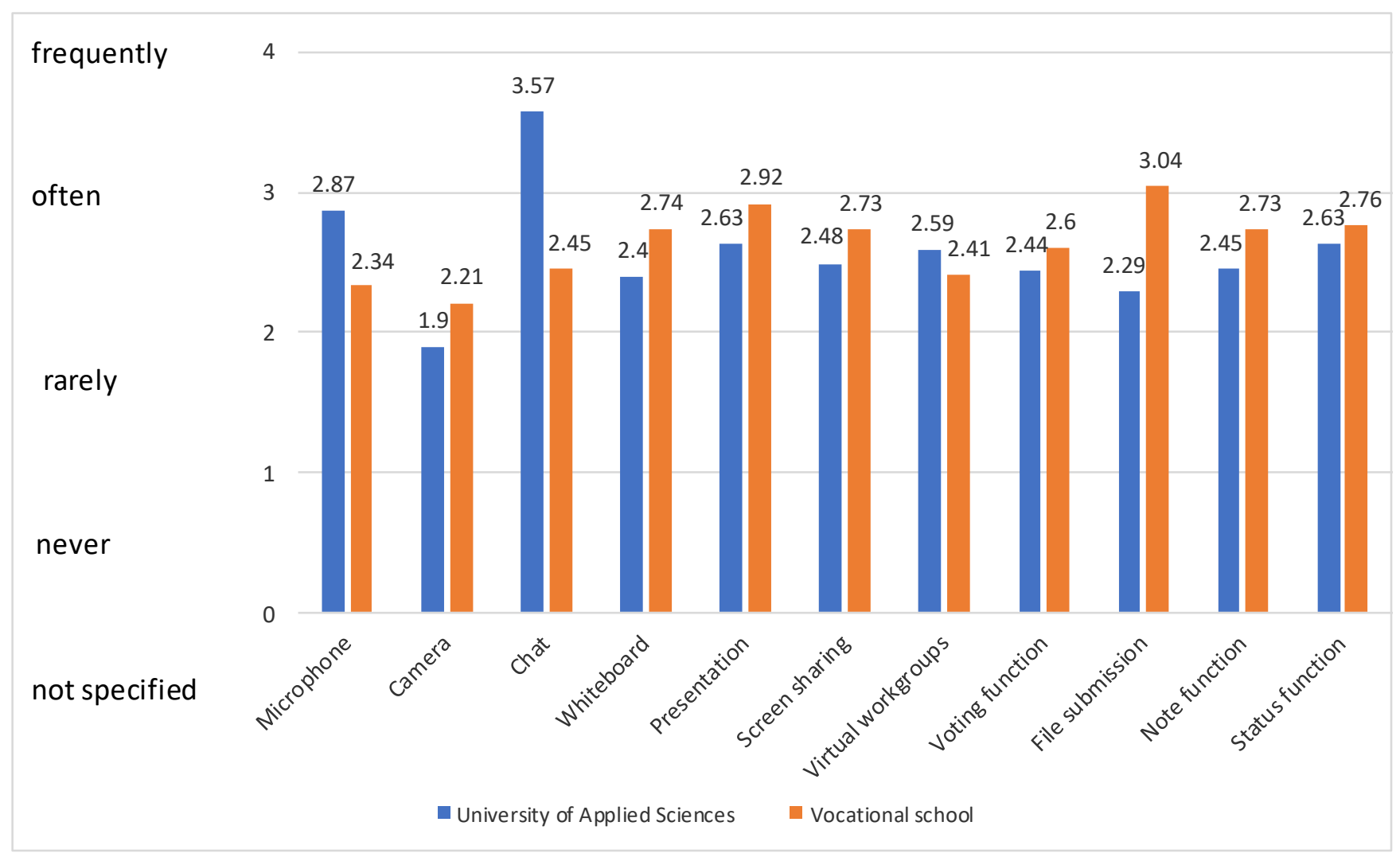

Figure 4. Using Adobe Connect ${ }^{\mathrm{TM}}$ tools (Mean comparison)

However, the tools "camera", "virtual working groups" and "status functions" show a deviation regarding the median values toward the scales "never" and "rarely" at the university. An increased deviation occurs in the sample of the vocational schools. Here, the mean value is higher than the median (especially in the tools "microphone", "camera", "whiteboard", "screen sharing", "voting function" and "status function"). Nevertheless, the $\chi^{2}$ test shows high significance ( $p=0.002$ to $p=$ 0.000 ) for the university sample, except for the "status function" tool.

\section{Discussion}

As has become apparent in the survey, respondents had little experience in dealing with virtual learning environments among the two samples, which makes the challenges in ad hoc implementation of educational offerings in a tight timeframe even more noteworthy.

It can be assumed that due to the many students and pupils as respondents, the perspective of the target groups of the educational offerings has been expressed here in the mean value comparison. The data shows a significant increase in teachers' usage patterns with each tool. They increasingly use the microphone, whiteboard, presentation, screen sharing, and hint functions. Using small group work also plays a major role here.

Reflecting on one's actions as a teacher at this point requires rethinking the previously familiar tasks as a learning advisor and learning facilitator to meet the recent digital challenges. Not only is the increasing adoption and mastery of the tools of ILIAS ${ }^{\mathrm{TM}}$ and Adobe Connect ${ }^{\mathrm{TM}}$ are crucial here, but also didactic interventions to provide adequate learning arrangements as an essential task of learning guidance need to be considered. Since the learning environment was not chosen voluntarily by 
teachers and students but was determined by the lockdown through COVID-19, it is a joint exploration of possibilities to advance analysis of existing learning strategies and support for changing them. Particularly, if learning counsellors and learning guides provide learners' orientation, they also must work on their orientation in the new learning environment. This shows how everyone can become a learner.

This snapshot encourages further consideration of the continued promotion of the learning potential of the tools, and continued expansion of other concepts offerings at the selected institutions in the surveys. Even if the convictions were not immediately obvious as to whether the learned use of the tools in ILIAS ${ }^{\mathrm{TM}}$ and Adobe Connect ${ }^{\mathrm{TM}}$ can be continued after the pandemic, this topic has, however, also stimulated reflection on what an acceptable ratio of presence and online portions in teachinglearning processes might look like.

\section{Summary and conclusion}

The question about the frequency of different tools in an online learning platform or a web conferencing format could only provide first insights. This snapshot stimulates discussion regarding continued disclosure about the learning potential of the tools. Future research and data analysis should examine the extent to which the use of the tools in ILIAS ${ }^{\mathrm{TM}}$ and Adobe Connect ${ }^{\mathrm{TM}}$ will evolve after the pandemic and how blended scenarios of face-to-face and online learning will design teachinglearning processes (as shown in figure 5).

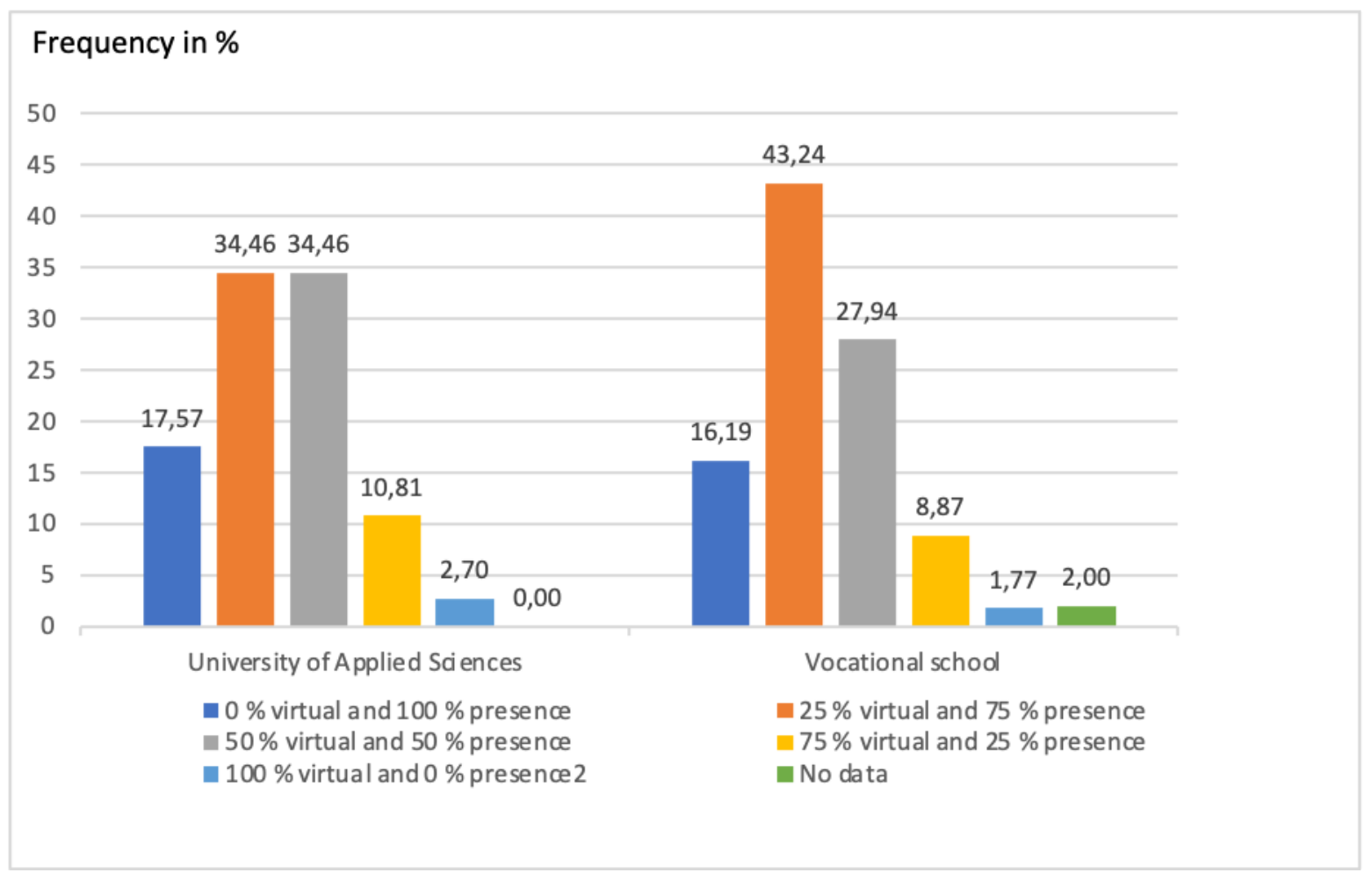

Figure 5. Proportion of face-to-face and online parts in teaching-learning processes

In both the higher education and the vocational education sector, teaching and learning with an exclusive presence component are only demanded by 16-17\%. The acceptance of integrating teaching-learning offers with presence and online character in the sense of blended learning 
approaches is now much more in focus. While at the University of Applied Sciences online teaching is equally distributed between $25 \%$ and $50 \%$, the respondents at the school are more in favour of a solution with a $25 \%$ virtual teaching approach. In both samples, virtual-only teaching-learning offerings are rejected by a majority. This result suggests that the development toward virtual teaching, which has become necessary under the forced conditions of the lockdown, might also change the teaching and learning processes in the sense of a target group- and demand-oriented didactics.

As the following research step, the analysis of critical situations should lead to developing new ideas on how the further tasks of learning guidance and counselling such as support to uncover barriers to learning, encourage learners' engagement with learning offers, support to discover learning needs, etc. can be worked out.

\section{References}

Adobe Systems Software Ireland Limited (06/2020). Handbuch Adobe Connect. Retrieved from https://helpx.adobe.com/de/adobe-connect/using/user-guide.html [26/10/2021].

Bortz J., Döring N. (2006).Forschungsmethoden und Evaluation in den Sozial- und Humanwissenschaften. Springer-Lehrbuch. Springer, Berlin, Heidelberg.

Brosius, F. (2017). SPSS 24 für Dummies. Deutschland: Wiley.

Böhm, J., Görl-Rottstädt, D., \& Wiesner, G. (2009). Vergleich ausgewählter Bilanzierungsverfahren für non-formal und informell erworbene Kompetenzen von Weiterbildnerinnen und Weiterbildnern Ausblick auf einen weiterführenden praktikablen Ansatz. Retrieved from http://tudresden.de/die tu dresden/fakultaeten/erzw/erzwibp/eb/forschung/REPORT.pdf [26/10/2021].

Dyrna, J., Riedel,J., \& Schulze-Achatz, S. (2018). Wann ist Lernen mit digitalen Medien (wirklich) selbstgesteuert? Ansätze zur Ermöglichung und Förderung von Selbststeuerung in technologieunterstützten Lernprozessen. In Köhler, Th. Schoop, E., \& Kahnwald, N. (Eds.), Gemeinschaften in neuen Medien. Forschung zu Wissensgemeinschaften in Wissenschaft, Wirtschaft, Bildung und öffentlicher Verwaltung (pp. 155-166). Dresden: TUDpress. Retrieved from https://tud.qucosa.de/api/qucosa\%3A33827/attachment/ATT-0/ [26/10/2021].

Euler, D. \& Seufert, S. (2005). E-Learning in Hochschulen und Bildungszentren. Bd. I. München: Oldenbourg

Görl-Rottstädt, D., Pittius, K. (2018). Professionalisierungstendenzen in der Sozialen Arbeit im Kontext von Medienbildung und Medienpädagogik, In: Köhler, T., Schoop, E., Kahnwald, N. (eds.) Gemeinschaften in neuen Medien. Forschung zu Wissensgemeinschaften in Wissenschaft, Wirtschaft, Bildung und öffentlicher Verwaltung, TUDpress, Dresden (2018), pp. 114-121, https://nbnresolving.org/urn:nbn:de:bsz:14-qucosa2-336844 [18/07/2021].

Görl-Rottstädt, D., König, K., Pittius, K. (2020). Selbstbestimmtes und selbstorganisiertes Gestalten von Selbststudienzeiten - Ein Vergleich klassischer und digitaler Ansätze von Lernberatung und Lernbegleitung im berufsbegleitenden Studium, In: Schutt-Pfeil, G., Gaisch, M., Darilion, A. (eds.) 8. Tag der Lehre der FH OÖ, Digital only. Moodle course from $18^{\text {th }}-25^{\text {th }}$ may 2020 (2020), pp. 63-73, Kontextdruck, Linz https://www.fh-ooe.at/fileadmin/user_upload/fhooe/landingpages/tag-derlehre/2021/docs/Tagungsband_8._TdL_FH_O\%C3\%96_2020.pdf [18/07/2021].

Görl-Rottstädt, D., Riedel, J., König, K., Pittius, K. (in press). Zwischen digital und analog - Ein Vergleich klassischer und digitaler Ansätze von Lernberatung und Lernbegleitung im berufsbegleitenden Studium, Tagung „Perspektiven für den Studienerfolg - Gelingensbedingungen, Stolpersteine, Wirkungen“, virtuelle Tagung der Technischen Universität Kaiserslautern und der Hochschule Kaiserslautern, $02^{\text {th }}-03^{\text {th }}$ September 2020.

Gössling, B., \& Daniel, D. (2018). Video analysis in Design-Based Research-Findings of a project on self-organised learning at a vocational school. EDeR. Educational Design Research, 2(2). 
Hermann-Ruess, A. \& Ott, M. (2014). Das gute Webinar: Das ganze Know How für bessere OnlinePräsentationen, ein Praxisratgeber: Online präsentieren und Kunden gewinnen. 2. ed. Wiesbaden: Springer.

Heyse, V. \& Erpenbeck, J. (1997). Der Sprung über die Kompetenzbarriere. Bielefeld.

ILIAS open source e-Learning e.V. (2020). Ilias - Bedienungsanleitung für Lehrende. Köln. Retrieved from https://iliasdocuworld.qualitus.de/goto.php?target=lm 124 [26/10/2021].

Kruse, U. \& Wiesner, G. (2002). Gezielte Unterstützung selbstgesteuerten Lernens Erwachsener durch Weiterbildungsinstitutionen - Ergebnisse empirischer Untersuchungen. In Kraft, S. (Ed.), Selbstgesteuertes Lernen in der Weiterbildung (pp. 159-175). Baltmannsweiler: Schneider Verlag Hohengehren GmbH.

Kubrická, J. (2020). Academic Self-Organised Learning Environment-the lessons to be learned and taught. CASALC Review, 10(2), 83.

Moriz, W. (2008). Blended-Learning: Entwicklung, Gestaltung, Betreuung und Evaluation von ELearningunterstütztem Unterricht. Norderstedt: BoD.

Nolda, S. (2012). Einführung in die Theorie der Erwachsenenbildung. Darmstadt: WBG.

Pätzold, H. (2004). Lernberatung und Erwachsenenbildung. In Arnold, R. (Ed.), Grundlagen der Erwachsenenbildung. Bd. 41. Baltmannsweiler: Schneider Verlag Hohengehren GmbH.

Promotionskolleg Lebenslanges Lernen (2003). Lebenslanges Lernen - Theoretisches Konzept und bildungspolitische Vision -Forschungsprogramm des Promotionskollegs. Retrieved from http://www.tu-dresden.de/kollegLLL/Forschungsprogramm.pdf [13/09/2004].

Siebert, H. (2011). Lernen und Bildung Erwachsener. Bielefeld: Bertelsmann.

Wiesner, G., Böhm, J., Görl-Rottstädt, D. \& Mattick S. (2009c). Kompetenzpass für Weiterbildner/innen Erwachsenenpädagogische Kompetenzen bilanzieren- Fremdeinschätzung. Retrieved from http://www.tudresden.de/die_tu_dresden/fakultaeten/erzw/erzwibp/eb/forschung/Gesamt_FE.pdf [26/10/2021].

Wiesner, G., Böhm, J., Görl-Rottstädt, D., \& Mattick S. (2009b). Kompetenzpass für Weiterbildner/innen Erwachsenenpädagogische Kompetenzen bilanzieren- Selbsteinschätzung. Retrieved from http://www.tudresden.de/die_tu_dresden/fakultaeten/erzw/erzwibp/eb/forschung/Gesamt_SE.pdf [26/10/2021].

Wiesner, G., Böhm, J., Görl-Rottstädt, D., \& Mattick S. (2009a). Kompetenzpass für Weiterbildner/innen Erwachsenenpädagogische Kompetenzen bilanzieren- Handreichung. Retrieved from

dresden.de/die_tu_dresden/fakultaeten/erzw/erzwibp/eb/forschung/Gesamt_Handreichung.pdf [26/10/2021].

Wiesner, G., Kruse, U., Frenzel, S., et al. (2002a). Erweiterung von Selbstlernkompetenzen Erwachsener - Weiterentwicklung professionellen Handelns der Weiterbildner zur Initiierung und Begleitung selbstgesteuerter Lernprozesse, Modul Selbstgesteuertes Lernen. Dresden: Technische Universität Dresden.

Wiesner, G., Kruse, U., Frenzel, S., et al. (2002b). Erweiterung von Selbstlernkompetenzen Erwachsener - Weiterentwicklung professionellen Handelns der Weiterbildner zur Initiierung und Begleitung selbstgesteuerter Lernprozesse. Modul Lernberatung. Dresden: Technische Universität Dresden. 